\title{
To A Complaint Crime Implementation of Sexual Violence of Husband to Wife in Polres Cirebon Jurisdictions
}

\author{
Yanto Irianto ${ }^{1}$
}

\begin{abstract}
The smallest element of a country's society is the family. In the ship sailed home life husband and wife, conflicts between husband and wife which can lead to legal consequences. One of the conflicts in the home that can lead to the legal consequences of sexual violence husbands against wives. During this time, in case of sexual assault on a particularly husbands against wives, most victims of violence choose to divorce, few victims are willing to bring a criminal case is processed. The application to a complaint of a criminal offense of sexual violence is seen by some experts as a barrier to criminal law enforcement against criminal acts of domestic violence.The method used in this research is normative juridical. The results showed that a complaint of the victim is an absolute condition that must exist in the criminal justice process either under investigation or under prosecution in the case Sexual violence husband to wife. Complaints of victims is the most important thing in a crime that qualifies to a complaint. Without complaint the victim, the criminal justice process will not run.

Keywords: Complaints Offense; Elimination; Sexual Violence.
\end{abstract}

\section{Introduction}

The smallest element of a country's society is the family. Welfare, tranquility and harmony in a large community (nation) is very dependent on the well-being, tranquility, and harmony of the family. The family formed through marriage. According to Article 1 of Act No. 1 of 1974 on Marriage, "marriage is the emotional and physical bond between a man and a woman as husband and wife someone with the aim of forming a family (household) who are happy and everlasting based on God". Furthermore, according to Article 2, paragraph 1 of Act No. 1 of 1974 on Marriage, "marriage is legal if it is done according to the law of eachs religion and belief".

During this time, in case of domestic violence, most victims of violence choose to divorce by the Marriage Act, few victims are willing to bring a criminal case is processed. The views of people who think that the problem of domestic violence is marital affairs are concerned, which must be completed by both of them, also slows the protection of women. Communities also argues that the intervention of other parties such as family, community, and government considered unusual. ${ }^{2}$

Domestic violence before the Act No. 23 of 2004 on the Elimination of Domestic Violence usually charged under Article 351 of the Criminal Code of persecution against father, mother, husband, wife, or child and penalties are added to the third. The provision does not explicitly regulate the violence in the family, but at least it can be used to denounce the perpetrators to the police and as the basis for criminal litigation in court. ${ }^{3}$

However, the Criminal Code is considered not to protect women (wives) of acts of violence

\footnotetext{
${ }^{1}$ Student of Master of Law, Universitas Islam Sultan Agung Semarang and Advocates Email: pancaranhati.cirebon@gmail.com

${ }^{2}$ Gema Pria KDRT sudah bukan zamannya lagi .... Tuesday October 102006

3 Anisfrianti Damanik 2004 Sistem Peradilan Pidana Terpadu bagi Perempuan Korban Kekerasan dalam Rumah Tangga (paper presented at the National Seminar on Elimination of Domestic Violence Law and the Role of Law Enforcement)
} 
committed by men (husband). This is in accordance with what is stated by Rita Serena Kalibonso, ${ }^{4}$ that the main issues relating to violence against women, centered on the absence of a law that specifically provide protection for women who are victims of violence, even the term violence against women is not known in Indonesian law. In addition, the problem Violence against women is also a global problem associated with the comforts of life, health and human rights. ${ }^{5}$

In Act No. 23 of 2004 on the Elimination of Domestic Violence, has arranged more specifically about violence in the household. Qualifying violence in Article 5, ie that.

"Everyone is prohibited from engaging in domestic violence against people in the scope of the household by means of: physical abuse; psychological violence; sexual violence; or neglect of household. "

Article 8 of Act No. 23 of 2004 on the Elimination of Domestic Violence, more specifically to sexual violence. Sexual violence includes:

- forcing sexual intercourse carried out against an individual living within the scope of the household;

- forcing sexual intercourse against one in the scope of the household with another person for commercial purposes and / or specific purpose.

Cirebon, noted that in 2017 a report by 9 (nine) cases of sexual violence against wives form of coercion to perform sexual intercourse by her husband.

Causes of sexual violence in the home can not be separated from the psychic state of couples having sexual relations, as their frigidity for women and sadism. Their frigidity is caused by: $:^{6}$

- moral cultivation of parents who are too harsh and strict when equip the meaning of the privacy of the female genitals

- lack of emotional closeness with their sexual partners, often frigidity is a result of insecurity, disbelief or hatred associated with lack of emotion with their sexual partner

- pair rough attitude and less acceptable to the patient frigidity

- the fear of pregnancy

- tendencies latent lesbianism or indeed the patient was a lesbian

While sadism ${ }^{7}$ is a psychological phenomenon that usually occurs in men where he would obtain sexual gratification through the screams and shouts partner who suffer from physical abuse does during sexual intercourse.

Marital sexual violence, for this is still considered taboo to be lifted to the surface, because many of them think that it is included in the private sphere, and values in society still considers the action experienced is a consequence and has become the nature of women. Although in reality it is not uncommon actions caused victims, especially women, experienced a great suffering and leaving the trauma for victims of violence.

Acts of violence or Violence, is primarily a concept of "Whose The meaning and content depends on the sosiety it self," ${ }^{8}$ as stated by Michael Levi, ${ }^{9}$ violence is an ambiguous term

\footnotetext{
${ }^{4}$ Rita Serena Kalibonso Penyelamat Wanita dan Keluarga a paper in a seminar in Jakarta

${ }^{5}$ Research and Human Rights Violence Against Women And Arrangements In Laws Jakarta 2003.

6 Sawitri Supardi Sadarjoen 2005 Bunga Rampai Kasus Gangguan Psikoseksual Refika Aditama Bandung p. 13

7 Ibid p. 18

8 Harkristuti Harkrisnowo Jurnal Legislasi Indonesia Regulations DG -undangan Dep. Justice and Human Rights July 2004 p. 22.
} 
meaning is estabilished trough Whose political process. Whatever its shape when viewed from the violence has an effect very traumatic for women, either associated or not with the nature of women themselves. ${ }^{10}$ Penalties are given for the ban on sexually violent conduct contained in Article 46 of Act No. 23 of 2004 on the Elimination of Domestic Violence.

The formulation of the crime of sexual violence in the household in the Act. This law qualified into two offenses, namely if the husband or wife is victim to a complaint, and when the victims outside their wife / husband became a regular offense. To a complaint is offense - the offense that the prosecution was based on the request of the victim or patient. $^{11}$

Loaded to a complaint the prosecution hung on the victim, and in some ways more favorable to victims of not prosecuting it than if prosecution. While this violence gives a very heavy impact for victims. The purpose of protection for victims of sexual violence in the household may not be achieved if the alleged victim did not complain or have no desire to prosecute.

\section{Research Methods}

This paper was prepared using the research method of juridical normative and through these methods can be analyzed laws regulating to a complaint in the case of sexual violence as well as the theory of legal experts in literature and works - scientific work law and to explain some of the terms and understanding, then use the dictionary.

\section{Results and Discussion}

\subsection{Domestic violence}

Definition of juridical violence can be seen in Article 89 of the Penal Code, namely: "to make people unconscious or helpless equated with violence." As defined faint memory loss or not conscious of itself. Then, who is helpless can be interpreted not have the strength or power at all so not able to conduct any resistance at all, but someone who is helpless that they can find out what happened to him. ${ }^{12}$

Article 1 of the Declaration on the Elimination of violence against women contain a definition of violence against women, namely:

"Violence against women is any act based on gender differences that result in misery or suffering physical, sexual or psychological, including threats of specific acts; coercion or arbitrary deprivation of liberty, whether occurring in public or in private life. "

In addition, Act No. 23 of 2004 on the Elimination of Domestic Violence, Domestic Violence formulated in Article 1: "Domestic violence is any act against someone, especially women, who caused misery or suffering physical, sexual, psychological, and / or negligence of household, including the threat to commit acts, coercion, or deprivation of liberty unlawfully within the scope of home stairs."

\footnotetext{
9 Michael Levi (1994) Violet Crime in The Oxford Book of Criminologi hand edited by Mike Maguire Rod Morgan and Robert Rainer Oxford Clarendon Press. p. 295-353.

10 Harkristuti Harkrisnowo Ibid.

11 Martiman Prodjohamidjojo 1997Memahami Dasar-Dasar Hukum Pidana Indonesia 1 Pradnya Paramita Jakarta

${ }^{12}$ Rika Saras Wati 2006 Perempuan dan Penyelesaian Kekerasan Dalam Rumah Tangga PT. Citra Aditya Bakhti Bandung. p. 13.
} 
Based on the above understanding, the terminology of violence against the victim has the characteristics that these measures: can be physical, sexual or psychological; can be either active or passive way (not done); desired / diniati by the offender, there is a cause / possible adverse effects on the victim (physical, sexual or psychological), which is not desired by the victim.

\subsection{Forms of Domestic Violence}

- Physical violence, directly in the form of beatings, pencakaran until the destruction of the vagina (sexual assault) and indirect physical violence that usually hit the table, slamming doors, breaking dishes, glasses, place flowers and others, as well as brute force.

- Psychological violence, psychological violence is an act that resulted in fear, loss of confidence, loss of ability to act, a sense of helplessness, and / or psychic suffering on someone.

- Sexual violence, sexual violence is any act that is in the form of forcing sexual intercourse, forced sexual relations by way of unnatural and / or disliked, forcing sexual intercourse with another person for commercial purposes and / or specific purpose. does not meet the sexual needs of his wife.

- Economic violence, such as the withholding of living during the marriage or living restrict arbitrarily, tolerating or even force their wives to work hard, do not give a living after a divorce even though the court ruled.

- Neglect of household is someone who neglected persons in the scope of the household, whereas according to the applicable law for him or for the approval or agreement he is obliged to provide life, care, or maintenance to the person. In addition, neglect also applies to anyone bringing about economic dependence by limiting and / or bar to work properly inside or outside the home so that the victim was under the control of the person's

A mix of violence, as mentioned above, either physical, psychological, and economical. From the description of the various forms of domestic violence, it is known that the violence is an act that is out of control that can be custom malware that can hurt your partner.

\subsection{Domestic Sexual Violence}

The word "sex" in the English language is defined by gender. The word "sex", the general public is always interpreted as copulation relationships between men and women. Marzuki Umar Sa'abah reminded ${ }^{13}$ "Addressed the issue of sexuality was not simple as imagined, or not as most people understand. Discussion on the issue of sexuality has been neutered lust and descent. As if there are only two categories of human sexuality, namely a) the moral sexuality, as a good and healthy sexuality, b) sexuality is immoral, as sexuality sick and evil".

Therefore, Marzuki Umar Sa'abah ${ }^{14}$ points out, "human sexuality in general can be grouped into three, namely: biological (physical pleasure and offspring); social (sexual relations, various social rules as well as various social forms through which embodied the

\footnotetext{
${ }^{13}$ Marzuki Umar Sa'abah 1997 Seks \& Kita Gema Insani Press Jakarta p. 15

${ }^{14}$ Ibid.
} 
biological sex), and subjective (individual and collective consciousness as an object of sexual desire).

In juridical, Article 8 of Act No. 23 of 2004 on the Elimination of Domestic Violence, more specifically to sexual violence in the household. Sexual violence includes: a) forcing sexual intercourse carried out against an individual living within the scope of the household; $b$ ) forcing sexual intercourse against one in the scope of the household with another person for commercial purposes and / or specific purpose.

\subsection{Married Sexual Violence as a criminal act}

Offense / criminal acts of complaint is the offenses that the prosecution was based on the request of the victim or patient. ${ }^{15}$

In the theory of criminal law, ${ }^{16}$ there are two types to a complaint that is:

a. To a complaint absolute, Is the offense (criminal act) that always only be prosecuted if a complaint was referred to in the articles: 284, 287, 293, 310 and the next, 332, 322, and 369. The complaint in this case it is necessary to prosecute the event, so that demand in its complaint should read: "I ask that this event is required."

Therefore demanded that the event, then all that has to do (do, induce, assist) with the event should be prosecuted, so to a complaint can not be split. A husband if he has to enter a complaint against adultery (Article 284) that has been done leh his wife, he can not desire that men who had committed adultery with his wife was charged, but against his wife (because he is still in love) do not prosecution.

b. To a complaint relative, Are offenses (criminal act) which is usually not a complaintbased offense, but if done by relatives specified in Article 367, then became to a complaint. Offenses such complaint this relative in the articles: $367,370,376,394,404$, and 411. In this case, the complaint was necessary not to prosecute the events, but to sue rang his guilty in the incident, so it can be cleaved to a complaint.

A father whose goods were stolen (Article 362) by two children named $A$ and $B$, can lodge a complaint just a single one of the two children, for example $A$, so $B$, can not be prosecuted. Requests demanding in its complaint in this regard must be hiding: "I ask my son who is named $A$ required".

The criminal acts of sexual violence in the household in the Law on Elimination of Domestic Violence be classified into two offenses, namely if the husband or wife is victim to a complaint, and when the victims outside their wife / husband became a regular offense.

\section{Closing}

\subsection{Conclusion}

- To a complaint in the crime of sexual abuse by the husband to wife are regulated in the Law on the Elimination of Domestic Violence can be a means of law enforcement for the victims. The complaint is a necessary condition that must exist in the criminal justice process either under investigation or under prosecution. Complaints of victims is the most important thing in a crime that qualifies to a complaint. Without complaint

\footnotetext{
15 Martiman Prodjohamidjojo 1997 Memahami Dasar - Dasar Hukum Pidana Indonesia 1 Pradnya Paramita Jakarta p. 69.

${ }^{16}$ R. Soesilo 1985 “Kitab Undang-Undang Hukum Pidana (KUHP)" Politeia Bogor. p. 87
} 
the victim, the criminal justice process will not run. Awareness and courage of victims to denounce sexual violence in this very necessary.

- Qualification to a complaint in the crime of sexual abuse by husband to wife has not proven effective in the present. Qualification to a complaint in the crime of sexual abuse by the husband to wife in the future will be effective if the victims have the awareness and the courage to denounce sexual violence to the police, especially if there has been a positive change in the legal culture in society and the victims have been economically empowered (capable of living independently).

\subsection{Suggestion}

Prevention of sexual violence the husband to wife very long-term should have been able to be supported by a number of other measures that are closer to the target, for example:

- Socialization to the public to make them aware of domestic violence, its impact, and prevention and treatment

- Socialization and increased understanding of law enforcement and other relevant authorities regarding Domestic Violence, including the impact and prevention and detection.

- Socialization and increased understanding of law enforcement, health, social workers and other relevant authorities regarding the protection of victims of domestic violence, including their rights.

- Enhancement and dissemination of one-stop shelter (victims of trustees institution) to accommodate people who are victims.

\section{Bibliography}

[1] Anisfrianti Damanik, Sistem Peradilan Pidana Terpadu bagi Perempuan Korban Kekerasan dalam Rumah Tangga (paper presented at the National Seminar on Elimination of Domestic Violence Law and the Role of Law Enforcement), Yogyakarta, 2004.

[2] Gema Pria, KDRT sudah bukan zamannya lagi ...., Tuesday, October 10, 2006,

[3] Harkristuti Harkrisnowo, Domestic Violence, Jurnal Legislasi Indonesia, Regulations Ministry of Justice and Human Rights, July 2004

[4] Leni Musiani, Ketidakpuasan Seksual Picu KDRT, Harian Umum Kompas, Friday, December 22, 2005

[5] Martiman Prodjohamidjojo, Memahami Dasar-Dasar Hukum Pidana Indonesia 1, Pradnya Paaramita, Jakarta, 1997

[6] Michael Levi, Violent Crime in The Oxford hand book of Criminologi, edited by Mike Maguire Rod Morgan and Robert Rainer Oxford Clarendon press, 1994.

[7] R. Soesilo, Kitab Undang-Undang Hukum Pidana (KUHP) serta KomentarKomentarnya Pasal Demi Pasal, Politeia, Bogor, 1985.

[8] Research and Human Rights, Violence Against Women And Arrangements In Regulation Legislation, Jakarta in 2003.

[9] Rika Saras Wati, Perempuan dan Penyelesaian Kekerasan Dalam Rumah Tangga, PT. Citra Aditya Bakhti, Bandung, 2006.

[10] Rita Serena Kalibonso, Penyelamatan Wanita dan Keluarga, a paper in a seminar in Jakarta, 2 July 2005. 